DOI : 10.14746/rie.2017.11.1

\title{
Słowo wstępne
}

\section{Szanowni Czytelnicy,}

wraz z numerem 11, „Rocznik Integracji Europejskiej” wchodzi w drugą dekadę istnienia i obecności na rynku wydawniczym. Idea powstania pisma i intelektualna konceptualizacja jego zawartości nierozerwalnie związana była z przemianami w Unii Europejskiej, które przyniósł podpisany właśnie w grudniu 2007 r. traktat lizboński. Dzięki życzliwości władz dziekańskich powstałego w tym samym czasie Wydziału Nauk Politycznych i Dziennikarstwa UAM udało się uruchomić czasopismo, które w szerokim zakresie poruszało problemy integracji europejskiej zarówno w wymiarze politycznym, wojskowym, gospodarczym, społecznym, jak i kulturalnym.

Formuła pisma z czasem ulegała ewolucji. Ze względu na wszechobecność internetu, zrezygnowaliśmy z umieszczania najważniejszych dokumentów unijnych, doszliśmy też do wniosku, że nie ma potrzeby wyodrębniania działu przeglądy-komentarze i wystarczy jeden zwarty blok pod nazwą rozprawy i artykuły oraz dział recenzji. Trzymając się dobrych zasad przynależnych rocznikom, w rozprawach pozwalaliśmy autorom na szersze analizy i wypowiedzi aniżeli jest to praktykowane w kwartalnikach naukowych. Uważamy, że zdało to egzamin. Pismo znajduje coraz większy zasięg odbiorców, jest cytowane w renomowanych monografiach i periodykach naukowych oraz opracowaniach zagranicznych. Stopniowo też pnie się w rankingach parametryzacyjnych przeprowadzanych przez Ministerstwo Nauki i Szkolnictwa Wyższego. Jest indeksowane w renomowanych bazach danych.

Do stałej współpracy redakcyjnej udało nam się pozyskać znanych i cenionych naukowców z krajowych i zagranicznych ośrodków badawczych, na których to radach i opiniach mogliśmy i możemy zawsze polegać. W tym miejscu należy wspomnieć o dwóch członkach Rady Naukowej: ministrze spraw zagranicznych Rzeczypospolitej, profesorze Stefanie Mellerze i dwukrotnym ministrze spraw zagranicznych Polski i pełnomocniku Prezesa Rady Ministrów do spraw dialogu międzynarodowego Władysławie Bartoszewskim, których z poczuciem dużej straty pożegnaliśmy w 2008 i 2015 roku.

Numer 11 pisma, które oddajemy w Państwa ręce powstał we współpracy ze środowiskiem naukowym Katolickiego Uniwersytetu Lubelskiego. Profesorowie Andrzej Podraza i Tomasz Stępniewski przygotowali do druku część rozpraw i artykułów sporządzonych przez Józefa Fiszera, Pawła Olszewskiego, Adriana Chojana, Artura Adamczyka i Andrzeja Szabaciuka. 
